\title{
Electrochemical Recognition of Candida albicans
}

\author{
Hideaki Matsuoka*, Isao Karube*, Nguyen Thi Kim Nhung \\ and Shuichi SUzUKI*
}

\begin{abstract}
An antibody to Candida albicans was covalently immobilized on a membrane prepared from cellulose triacetate, 1,8-diamino-4-aminomethyloctane, and glutaraldehyde. The antibody bound membrane was set between a couple of glass cells containing $32 \mathrm{mM} \mathrm{KCl}$ and 8 $\mathrm{mM} \mathrm{KCl}$ respectively. The membrane potential was measured with $\mathrm{Ag} / \mathrm{AgCl}$ electrodes. Then, the membrane was reacted with $C$. albicans and its membrane potential was measured again. The membrane potential changed toward the positive side. On the other hand, the membrane showed no response to Escherichia coli, Bacillus subtilis, Bacillus licheniformis. However, it responded to Saccharomyces cereviciae, though membrane potential shifted toward the negative side. Analysis of the membrane potential and the microscopic observation of the immunoreaction suggested that the membrane has a strong affinity to $C$. albicans. The shift of the membrane potential due to the reaction with $C$. albicans was correlated with the concentration of $C$. albicans in the range of $10^{4}-5 \times 10^{5} \mathrm{cells} \cdot \mathrm{cm}^{-3}$.
\end{abstract}

\section{Introduction}

Recently the measurement of Candida albicans has become an important item in clinical analysis. C. albicans is found in human body even in normal conditions. However, unusual increase is observed when the immunological function is diminished by the administration of antibiotics, adrenocortical hormons, anti-tumor reagents, and immunosuppressive reagents ${ }^{1 \sim 3)}$. Increase of $C$. albicans induces various malfunctions or diseases. Therefore, the concentration of $C$. albicans in blood is an important indicator of the immunological function, which is important for the control of administration schedule of reagents mentioned above.

The measurement of $C$. albicans is performed by visual inspection of antibody-antigen (Candida species) aggregation on a glass plate. However this conventional method requires skillful techniques and hardly gives quantitative results. Moreover it is not useful for the automated continual measurement of the yeast. Therefore more simple and quantitative method for the determination of $C$. albicans is required.

The authors previously showed that antibody bound membrane is feasible for the selec-

* Research Laboratory of Resources Utilization, Tokyo Institute of Technology (Nagatsuta-cho, Midori-ku, Yokohama)

Key Words: Candida Albicans, Electrochemical Recognition, Membrane Potential, Immunosensor, Yeast tive determination of specific proteins, lipids, peptides, and hormons. The amount of bound substances were estimated either by potentiometric or by amperometric method. The potentiometric method is based on the membrane potential shift resulting from charge density change or ionic permeability change due to the adsorption of substances on the membrane $e^{4 \sim 6)}$. The amperometric method is also sensitive and used for the determination of various substances ${ }^{7 \sim 9)}$.

In this study, the potentiometric method is applied to the immunoassay of $C$. albicans. Since $C$. albicans has negative charge, the adsorption of the cells on the antibody-bound membrane may induce a considerable change of membrane potential. Feasibility of the antibody-bound membrane as the immunosensor for $C$. albicans is described.

\subsection{Materials}

\section{Experimental}

Anti-Candida antibody (Candida check No. 1, IgG fraction) was obtained from Sanko Pure Chemicals Co. (Tokyo). Cellulose triacetate, 1,8-diamino-4-aminomethyloctane, $70 \%$ glutaraldehyde were obtained from Eastman Kodak Co. (Rochester, N.Y.), Asahi Kasei (Tokyo), Tokyo Kasei (Tokyo) respectively. Candida albicans, Bacillus subtilis, Bacillus licheniformis, Escherichia coli, Saccharomyces cereviciae were cultured according to conventional methods described previously. Other reagents were of analytical grade or 
laboratory grade. Distilled water was used throughout the experiments.

\subsection{Preparation of antibody bound mem- brane}

Cellulose triacetate $(250 \mathrm{mg})$ was dissolved in $5 \mathrm{~cm}^{3}$ dichloromethane and $150 \mathrm{~mm}^{3} \mathrm{1,8-}$ diamino-4-aminomethyloctane was added and stirred for $20 \mathrm{~min}$. Then $50 \mathrm{~mm}^{3}$ of $70 \%$ glutaraldehyde was added to the mixture and stirred for $20 \mathrm{~min}$. The resulting homogeneous solution was spread on a glass plate and stood at $20^{\circ} \mathrm{C}$ under a dried atmosphere for 2 days. The membrane formed on the glass plate was cut into small sheets and peeled off the glass plate. After washed with distilled water, the membrane was reacted with $1 \%$ glutaraldehyde for $1 \mathrm{hr}$ at $25^{\circ} \mathrm{C}$ in a phosphate buffer solution ( $0.1 \mathrm{M}, \mathrm{pH} 7.0$ ). One sheet of the membrane was set on a watch glass and 200 $\mathrm{mm}^{3}$ of antibody solution (10 $\mathrm{mg}$ protein. $\mathrm{cm}^{-3}$ ) was put on the membrane. The glass was covered with another watch glass and reacted for overnight at $4^{\circ} \mathrm{C}$. Then the membrane was incubated in $0.1 \mathrm{M}$ glycine solution $\left(\mathrm{pH} \mathrm{7.7)}\right.$ at $25^{\circ} \mathrm{C}$ for $30 \mathrm{~min}$ in order to block residual aldehyde groups. The antibodybound membrane was washed with $0.5 \mathrm{M} \mathrm{NaCl}$ for $30 \mathrm{~min}$ and $0.1 \mathrm{M}$ phosphate buffer solutions for $30 \mathrm{~min}$ and stored at $4^{\circ} \mathrm{C}$.

\subsection{Measurement of membrane potential}

Figure 1 shows an experimental setup. Antibody-bound membrane was set between the glass cells and a couple of $\mathrm{Ag} / \mathrm{AgCl}$ electrodes were inserted in each compartment. About $5 \mathrm{~cm}^{3}$ of $32 \mathrm{mM}$ and $8 \mathrm{mM}$ of $\mathrm{KCl}$ solutions were added in the compartment I and II respectively. The electrode inserted into the compartment II was put to earth and the membrane potential was measured. The potential difference of the electrodes $\left(\Delta E_{\mathrm{b}}\right)$ was detected with an electrometer (Hokuto Denko Co., Model HE-101A) and displayed on a recorder.

When $\mathrm{pH}$ dependence of the membrane potential was examined, $1 \mathrm{mM}$ citrate solutions $(\mathrm{pH} 3.0,4.6,6.0)$ containing $\mathrm{KCl}(32 \mathrm{mM}$ or $8 \mathrm{mM}$ ) and $1 \mathrm{mM}$ phosphate buffer solutions $(\mathrm{pH} \mathrm{7.0,8.0)}$ containing $\mathrm{KCl}(32 \mathrm{mM}$ or 8 $\mathrm{mM}$ ) were used as electrolytes for membrane potential measurement.

\subsection{Immunoreaction}

$\mathrm{KCl}$ solution in compartment I was replaced

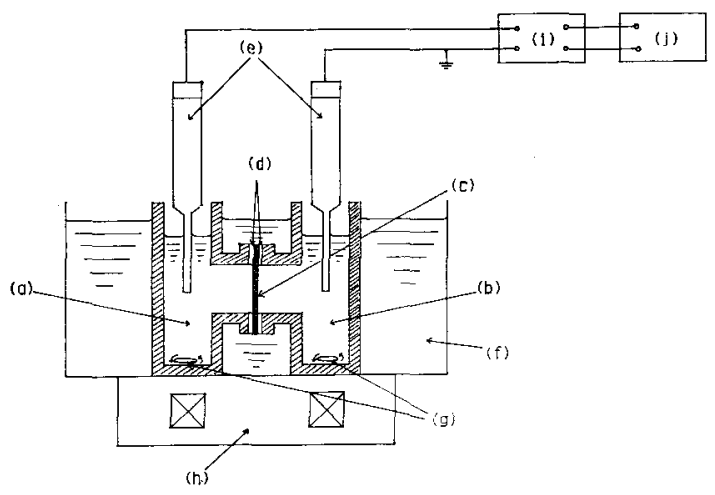

Fig. 1 Schematic diagram for electrochemical recognition system of microorganisms

(a): Compartment I, (b): Compartment II, (c): Antibody bound membrane, (d): Silicone rubber, (e): Ag/ $\mathrm{AgCl}$ electrodes, (f): Water bath, (g): Stirring bar, (h): Magnetic stirrer, (i): Electrometer, (j): Recorder

by a phosphate buffer solution containing microorganisms. On the other hand, the compartment II was filled with a phosphate buffer solution $(0.1 \mathrm{M}, \mathrm{pH} 7.0)$. After the reaction at $32^{\circ} \mathrm{C}$ for $30 \mathrm{~min}$, the membrane was washed with $0.5 \mathrm{M} \mathrm{NaCl}$ for $15 \mathrm{~min}$ and 0.1 M phosphate buffer ( $\mathrm{pH} 7.0$ ) for $15 \mathrm{~min}$.

\subsection{Measurement of membrane potential} after the immunoreaction

After washed, the glass cells were filled with $32 \mathrm{mM}$ and $8 \mathrm{mM} \mathrm{KCl}$ solutions respectively, and the membrane potential $\left(\Delta E_{\mathrm{a}}\right)$ was measured by the electrodes. The membrane potential changes $\left(\Delta E_{\mathrm{a}}-\Delta E_{\mathrm{b}}\right)$ were plotted against the microbial concentration.

\subsection{Microscopic observation of immuno- reaction}

The antibody used in the present study is known to react with at least 7 species of yeast. Therefore, the reactivity of the bound antibody to microorganisms applied in the present experiments was checked by a visual test using a microscope.

Microbial suspension was dropped on a slide glass and observed with a microscope $(\times 200)$. Then $10 \mathrm{~mm}^{3}$ of the antibody was dropped with microsyringe. Agglutination due to antigen-antibody reaction was observed. 


\section{Results and Discussion \\ 3.1 Membrane potential caused by $C$. albi- cans}

Before the immunoreaction, the membrane potentials were $28-32 \mathrm{mV}$. After the reaction with $C$. albicans $\left(10^{5}\right.$ cells $\left.\cdot \mathrm{cm}^{-3}\right)$, the membrane potential shifted about $2 \mathrm{mV}$ toward the positive side. The difference of the membrane potentials before and after the reaction $\left(\Delta E_{\mathrm{a}}-\Delta E_{\mathrm{b}}\right)$ was plotted against the $C$. albicans concentration as shown in Fig. 2. The membrane potential difference increased with increasing cell concentration in the ragne $10^{4}-5 \times 10^{5}\left(\right.$ cells $\left.\cdot \mathrm{cm}^{-3}\right)$. No change of the membrane potential was observed below $10^{4}$ $\left(\right.$ cells $\left.\cdot \mathrm{cm}^{-3}\right)$. Therefore, the order estimation of $C$. albicans concentration was possible in the range of $10^{4}-5 \times 10^{5}\left(\right.$ cells $\left.\cdot \mathrm{cm}^{-3}\right)$.

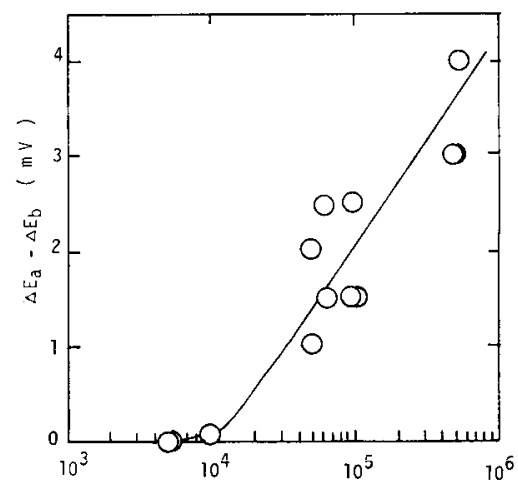

Cell concentration $\left(\mathrm{cm}^{-3}\right)$

Fig. 2 Correlation curve between $C$. albicans concentration and membrane potential change

\subsection{Membrane potential change caused by various microorganisms}

Bacteria observed in blood are classified into gram negative bacteria, gram positive bacteria and others (including yeast such as C. albicans). These bacterial groups are considerably different from each other in their cell surface structures and antigenic groups. Therefore, several bacteria belonging to each group were applied to the present system, in order to examine the selectivity of the antibody bound membrane.

When E. coli (gram negative) was applied, no change in the membrane potential was


Fig. 3 Correlation curves between other microorganisms and membrane potential changes

Dotted lines show correlation curves obtained in Fig. 2

observed, as shown in Fig. 3 (a). When $B$. subtilis or B. licheniformis (gram positive) was applied, the membrane potential shifted about $1 \mathrm{mV}$ toward the positive side. However, the extent of the change was independent of the cell concentration in the range $10^{4}-5 \times 10^{5}$ (cells $\cdot \mathrm{cm}^{-3}$ ) (Fig. 3(b), (c)). This might be due to non-specific adsorption of these microorganisms.

In contrast, the membrane potential shifted toward the negative side, when $S$. cereviciae was applied to the system (Fig. 3(d)). The extent of the membrane potential change increased with increasing the cell concentration in the range $10^{4}-5 \times 10^{5}\left(\mathrm{cells} \cdot \mathrm{cm}^{-3}\right)$.

Since $C$. albicans and $S$. cereviciae belong to the same family, they might have similar antigenic structures located on the surface of their cell wall. Therefore, at least one of these antigenic structures is common for both strains. Thus the antibody to $C$. albicans might respond to $S$. cereviciae.

\section{$3.3 \mathrm{pH}$ dependence of the membrane po- tential}

The antibody bound membrane has amino groups or carboxyl groups. The electric charge density changes with $\mathrm{pH}$ conditions. Therefore, the membrane potential was measured at various $\mathrm{pH}$. As shown in Fig. 4, the 


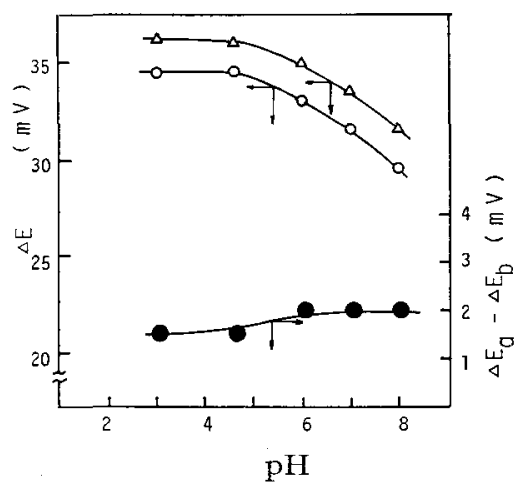

Fig. $4 \mathrm{pH}$ profile of membrane potential

$(0)$ : Before reaction, $(\Delta)$ : After reaction with $C$.albicans, (O): Membrane potential difference; $[(\Delta) \cdots(O)]$.

membrane potential was constant below $\mathrm{pH}$ 4.6 , while it gradually decreased above $\mathrm{pH}$ 4.6 .

After the reaction, the $\mathrm{pH}$ profile of the membrane potential shifted about $1 \mathrm{mV}$ toward the positive side, though the overall profile was almost similar to that obtained before the reaction. Therefore, the charge of the bound microorganisms was slightly affected by $\mathrm{pH}$.

\subsection{Dependence of ionic strength on the membrane potential}

The dependence of the membrane potential $(\Delta E)$ on the electrolyte concentration is approximated by the following equation when uni-uni valent electrolyte solutions are separated by a charged membrane, and the electrolyte concentration is very high relative to the charge density ${ }^{10 \sim 13)}$

$$
\Delta E=\frac{R T}{F}\left\{-\tau \ln r+\left(1+\frac{1}{r}\right) \frac{1-\tau^{2}}{2} \frac{\theta^{*}}{C_{2}}+\cdots\right\}
$$

where $r=C_{1} / C_{2} ; \tau=\left(\omega_{+}-\omega_{-}\right) /\left(\omega_{+}+\omega_{-}\right)$;

$$
\theta^{*}=\mathrm{X} \cdot\left(\gamma_{+} \gamma_{-} / k_{+} k_{-}\right)^{1 / 2}
$$

$C_{1}, C_{2}$ are the electrolyte concentration $\left(C_{1}\right\rangle$ $\left.C_{2}\right) ; \omega_{+}, \omega_{-}$are the molar mobilities of cation and anion in the membrane; $\mathrm{X}$ is charge density in the membrane $(X>0) ; \gamma_{+}, \gamma_{-}$are activity coefficients of cation and anion in the membrane; $k_{+}, k_{-}$are the distribution coeffcients of cation and anion at the membrane/ solution interface. Therefore, a plot of the membrane potential $(\Delta E)$ versus reciprocal electrolyte concentration $\left(1 / C_{2}\right)$ yields a straight line, and the gradient and the inter-



Fig. 5 Dependence of reciprocal concentration of $\mathrm{KCl}$ on the membrane potential

$(\bullet)$ : Before reaction, (O) After reaction with $C$, albicans.

cept at the ordinate $\left(1 / C_{2} \rightarrow 0\right)$ give values of $\tau$ and $\theta^{*}$.

Figure 5 shows the dependence of the membrane potential of the antibody bound membrane before and after the reaction with $C$. albicans. An approximated straight line was obtained in the range $1 / C_{2}<40$. From the gradients and the intercepts of the line at $1 /$ $C_{2}=0, \tau$ and $\theta^{*}$ were estimated. $\theta^{*}$ did not change due to the reaction with $C$. albicans as shown in Table 1 , while $\tau$ increased about $50 \%$. Therefore, the membrane potential change was ascribed responsible for the change in the ionic permeability. $C$, albicans has about several $\mu \mathrm{m}$ diameter. On the other hand, average pore size of the membrane is smaller than several hundreds $\AA$. Therefore, adsorption of $C$. albicans might diminish the effective area for ion permeation.

Table 1 Analytical results of the membrane potential change due to the reaction with $C$. albicans

\begin{tabular}{l|c|c}
\hline \hline & $\begin{array}{c}\theta^{*} \\
\left(\mathrm{~mol} \cdot \mathrm{cm}^{-3}\right)\end{array}$ & $\tau=\frac{\omega_{+}-\omega_{-}}{\omega_{+}+\omega_{-}}$ \\
\hline Before reaction & $4.8 \times 10^{-9}$ & 0.226 \\
After reaction & $4.7 \times 10^{-9}$ & 0.301 \\
\hline
\end{tabular}

On the other hand, analytical results obtained above suggested that the negative charge of $C$. albicans was lost due to the immunoreaction. When the membrane was reacted with $S$. cereviciae, the membrane 


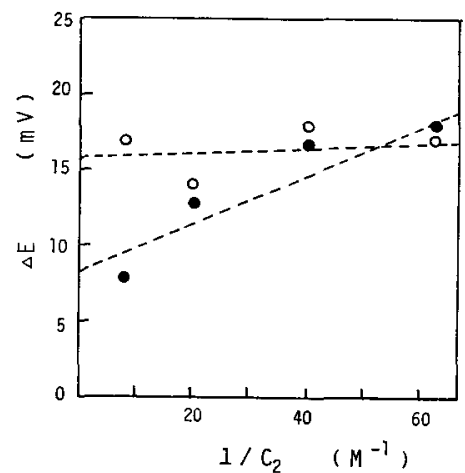

Fig. 6 Dependence of reciprocal concentration of $\mathrm{KCl}$ on the membrane potential

(•); Before reaction, (0): After reaction with $S$. cereviciae

potential showed a different profile as shown in Fig. 6. An approximated straight lines were derived by the least square method from the points measured under the conditions $1 / C_{2}<$ 62.5. From the gradients and the intercepts at $1 / C_{2}=0, \tau$ and $\theta^{*}$ were calculated as sum-
Table 2 Analytical results of the membrane potential change due to the reaction with $S$. cereviciae

\begin{tabular}{l|c|c}
\hline \hline & $\begin{array}{c}\theta^{*} \\
\left(\mathrm{~mol} \cdot \mathrm{cm}^{-3}\right)\end{array}$ & $\tau=\frac{\omega_{+}-\omega_{-}}{\omega_{+}+\omega_{-}}$ \\
\hline Before reaction & $1.7 \times 10^{-9}$ & 0.226 \\
After reaction & $0.2 \times 10^{-9}$ & 0.431 \\
\hline
\end{tabular}

marized in Table 2. The value of $\tau$ increased in a similar manner to the case of $C$. albicans. In sharp contrast, however, the charge density also changed in this case. The decrease of charge density was possibly due to the addition of negative charge of $S$. cereviciae ${ }^{14,15)}$ adsorbed on the membrane. It is not clear why $C$. albicans lost its negative charge while S. cereviciae maintained it.

\subsection{Microscopic observation of the immuno- reaction}

The antibody used in the present study is known to react with several strains of yeast other than $C$. albicans. Therefore, the antigenicity of $S$. cereviciae was checked by the

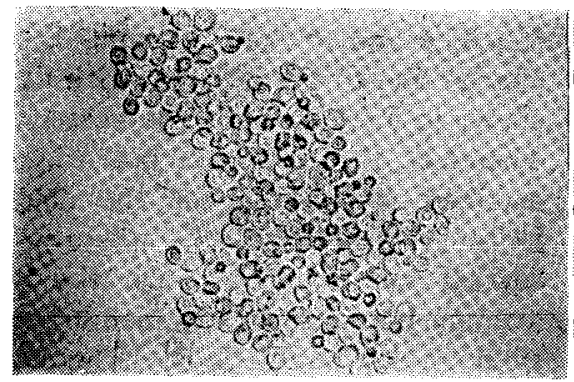

(a)



(b)

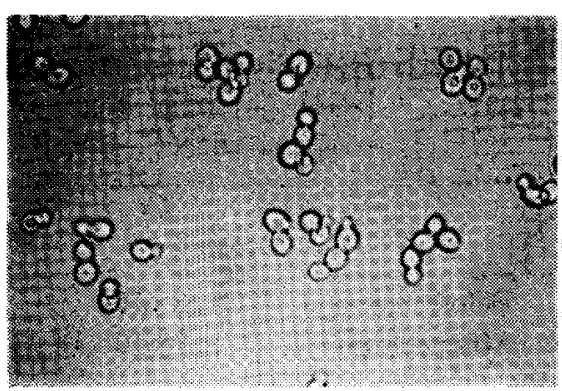

(c)



(d)

Fig. 7 Microscopic observations of immunoreaction $(\times 200)$

(a): C. albicans before reaction, (b): S. ceveviciae before reaction, (c): $C$, albicans after reaction with antibody, (d): S. ceveviciae after reaction with antibody 
conventional method. C. albicans or $S$. cereviciae suspension was dropped on a glass plate and observed with a microscope (Fig. 7(a), (b)). Then, $10 \mathrm{~mm}^{3}$ of antibody was added to each suspension. Within 2-3 min, aggregation occurred as shown in Fig. $7(\mathrm{c})$ and (d). The rate of aggregating reaction depends upon the concentration of aritibody and number of antigenic structures on the cell surface. The results of Figs. 7(c) and (d) demonstrate that $C$. albicans has much more antigenic groups to antibody used than $S$. cereviciae.

\section{Conclusion}

The immunosensor system proposed could recognize $C$. albicans in a sample solution. The measurement was based on the determination of membrane potential change which might be caused by the ionic permeability change. The use of specific antibody considerably improves specificity of biosensors. The results obtained demonstrate the feasibility of this system as the electrochemical determination of other microorganisms in biological fluids.

\section{References :}

1) T. J. Roger and E. Bulish, Microbiol. Rev. 44, 660 (1980).

2) T. E. Kiehn, Science 206, 577 (1979).

3) M. A. Persi and J. C. Burnham, Appl. Environ. Microbiol. 42, 364 (1981).

4) M. Aizawa and S. Suzuki, Proc. 13th Conf. Solid State Devices, Tokyo, 1981; Japan J. Appl. Physics 21, 219 (1982).

5) M. Aizawa, S. Kato and S. Suzuki, J. Membrane Sci. 2, 125 (1977).

6) M. Aizawa, S. Suzuki, Y. Nagamura, R. Shinohara and I. Ishiguro, J. Solid-Phase Biochem. 4, 25 (1979).

7) M. Aizawa, A. Morioka, H. Matsuoka, S. Suzuki, Y. Nagamura, R. Shinohara and I. Ishiguro, J. Solid-Phase Biochem. 1, 319 (1976).

8) M. Aizawa, A. Morioka and S. Suzuki, Anal. Chim. Acta 115, 61 (1980).

9) I. Karube, T. Matsunaga, S. Suzuki, T. Asano and S. Itoh, Anal. Chim. Acta, (submitted).

10) M. Nakagaki, Maku (Membrane) 1, 76 (1976).

11) M. Nakagaki, Maku (Membrane) 1, 321 (1976).

12) M. Nakagaki, Maku (Membrane) 2, 80 (1977).

13) S. Kato, M. Aizawa and S. Suzuki, J. Membrane Sci. 3, 29 (1978).

14) D. H. Northcote and R. W. Horne, Biochem. J. 51, 232 (1952).

15) G. H. Fleet and D. H. Manners, J. Gen. Microbiol. 94, 180 (1976).

(Received Aug. 31, 1982; Accepted Nov. 9, 1982)
(945 ページよりつヴき)

現在，大学または研究所での電気化学に関する研究は 大体次の通りである。国立ソウル大学校では透明 $\mathrm{SnO}_{2}$ 半導体修飾電極に括ける各種電気化学反応機構の解明, ポーラログラフィーによる基礎測定，アルミニウム陽極 酸化皮膜のカ゚ス通過特性, 電気化学的腐蝕, 防触树よび 金属析出機構に関寸名研究学行っている．漢陽大学校 (ソウル)では不飽和脂肪族アルコール類または芳香族力 ルボン酸類の有機電解反応, 各種メッキ浴の添加剤の開 発およびその電気化学的挙動, 析出ニッケルメッキ層の 析出機構の解明，鉛一カルシウム合金類または黄銅類な どの腐触メカニズムの究明，2次電池特性の改良などの 研究が進行中であり, 今後半導体電極による光電気化学 に関する研究も計画中である，延世大学校(ソウル)と西 江大学校(ソウル)ではニッケルおよび各種金属表面の酸 化メカニズムなどを光と電気化学的測定法により究明す る研究安行っている. 高麗大学校(ソウル)と蔚山工科大 学(蔚山)ではイオン選抧性電極の開登とその基礎的特性 などの研究が進行している。仁荷大学校(仁川)では電解
過塭素酸生成反応機構の解明および無機化合物の酸化一 還元反応の研究が進えでいる一方，金属の電解析出拉よ び電解精製なども研究中である.慶北大学校(大邱)では 非水溶液中でのポーラログラフィーによる基璴測定，海 洋大学(釜山)では海水などの水溶液中での金属の防蝕を 電気化学的比研究中であり, 東亜大学校(釜山) む有機電 解女行っている. 大学以外の韓国科学技術院(ソウル)に は電気化工研究室があり, 現在りチウム一塩素高温電池の 開発をアメリカの Battelle 研究所のチームと共同研究を 組えでいる。一方，腐触問題の解決も行っているがー次


による水の分解を行ったこともある。国立工業試験院 (ソウル)ではポーラマダラフィーなどを用いる基礎研究 と各種電気メッキによる金属の析出機構, メッキ方法の 改良などの研究を，また韓国機械金属研究所(慶南昌原) でも表面処理研究チームが電気メッキに関する研究が活 発に行なるれている。

(漢陽大学校工科大学教授 李 柱性 (Ju-Seong Lee) 